\title{
Frost risks in the Mantaro river basin
}

\author{
G. Trasmonte ${ }^{1}$, R. Chavez ${ }^{1}$, B. Segura ${ }^{1}$, and J. L. Rosales ${ }^{2}$ \\ ${ }^{1}$ Instituto Geofísico del Perú, Calle Badajoz 169, Mayorazgo IV Etapa, Ate, Lima 03, Peru \\ ${ }^{2}$ Universidad Nacional Federico Villarreal, Facultad de Ingeniería Geográfica y Ambiental, Peru
}

Received: 15 June 2007 - Revised: 21 August 2007 - Accepted: 22 August 2007 - Published: 10 April 2008

\begin{abstract}
As part of the study on the Mantaro river basin's (central Andes of Perú) current vulnerability to climate change, the temporal and spatial characteristics of frosts were analysed. These characteristics included intensity, frequency, duration, frost-free periods, area distribution and historical trends. Maps of frost risk were determined for the entire river basin, by means of mathematical algorithms and GIS (Geographic Information Systems) tools, using minimum temperature - 1960 to 2002 period, geomorphology, slope, landuse, types of soils, vegetation and life zones, emphasizing the rainy season (September to April), when the impacts of frost on agriculture are most severe. We recognized four categories of frost risks: low, moderate, high and critical. The critical risks (with a very high probability of occurrence) were related to high altitudes on the basin (altitudes higher than $3800 \mathrm{~m}$ a.s.l.), while the low (or null) probability of occurring risks were found in the lower zones (less than $2500 \mathrm{~m}$ a.s.l.). Because of the very intense agricultural activity and the high sensitivity of the main crops (Maize, potato, artichoke) in the Mantaro valley (altitudes between 3100 and $3300 \mathrm{~m}$ a.s.1.), moderate to high frost risks can be expected, with a low to moderate probability of occurrence. Another significant result was a positive trend of 8 days per decade in the number of frost days during the rainy season.
\end{abstract}

\section{Introduction}

The Mantaro river basin is located in the eastern slope of the Peruvian central Andes. It is a very rich area in agriculture and because of its geographical characteristics and complex topography, it is constantly affected by frosts. Excluding droughts, frosts are considered the most pressing atmospheric phenomenon to the local population because of

Correspondence to: G. Trasmonte

(grace@chavin.igp.gob.pe) their effects on agriculture, the region's main economic activity (IGP, 2005a). The Mantaro river basin and two other basins were selected to develop an integrated local assessment with a climate change perspective, as part of the first effort made in our country to map this phenomenon. In this paper, we present the main results of the analysis of frost events in the Mantaro river basin, including maps showing frost occurrences and frost risks for different intensities.

\section{Mantaro river basin, meteorological network and data used}

The Mantaro river basin is located in the central Andes of Perú, between the latitudes: $10^{\circ} 34^{\prime} \mathrm{S}-13^{\circ} 35^{\prime} \mathrm{S}$ and longitudes: $73^{\circ} 55^{\prime} \mathrm{W}-76^{\circ} 40^{\prime} \mathrm{W}$. It covers an area of approximately $34550 \mathrm{~km}^{2}$ in size. It is a complex Andean region with altitudes ranging from $500 \mathrm{~m}$ a.s.l. to $5350 \mathrm{~m}$ a.s.l., and a mean altitude of $3800 \mathrm{~m}$ a.s.l.

Daily minimum air temperatures ${ }^{1}\left(T_{\min }\right)$ for the 1960 2002 period were recovered from fifteen meteorological stations in the basin, as well as two additional stations located in adjacent areas (Fig. 1), for at minimum a ten year period. Six time series of at least 30 years long (Marcapomacocha, Cerro de Pasco, Jauja, Huayao, Pilchaca and Lircay) were considered for trend analysis.

Geographic information system (GIS) data for the Mantaro river basin was digitalized and/or compiled, then processed for the project. The basic GIS information included were orography, hydrography and main cities and towns among others; the considered thematic maps were geomorphology, slope, land-use, types of soils, vegetation and life zones, at scales of 1:100 000 and 1:250 000 for basic and thematic maps respectively. Resolution of the terrain model was $100 \mathrm{~m}$ by pixel, interpolated using the spline method.

\footnotetext{
${ }^{1}$ Measured at a standard height of $1.6 \mathrm{~m}$ above the surface.
}

Published by Copernicus Publications on behalf of the European Geosciences Union. 


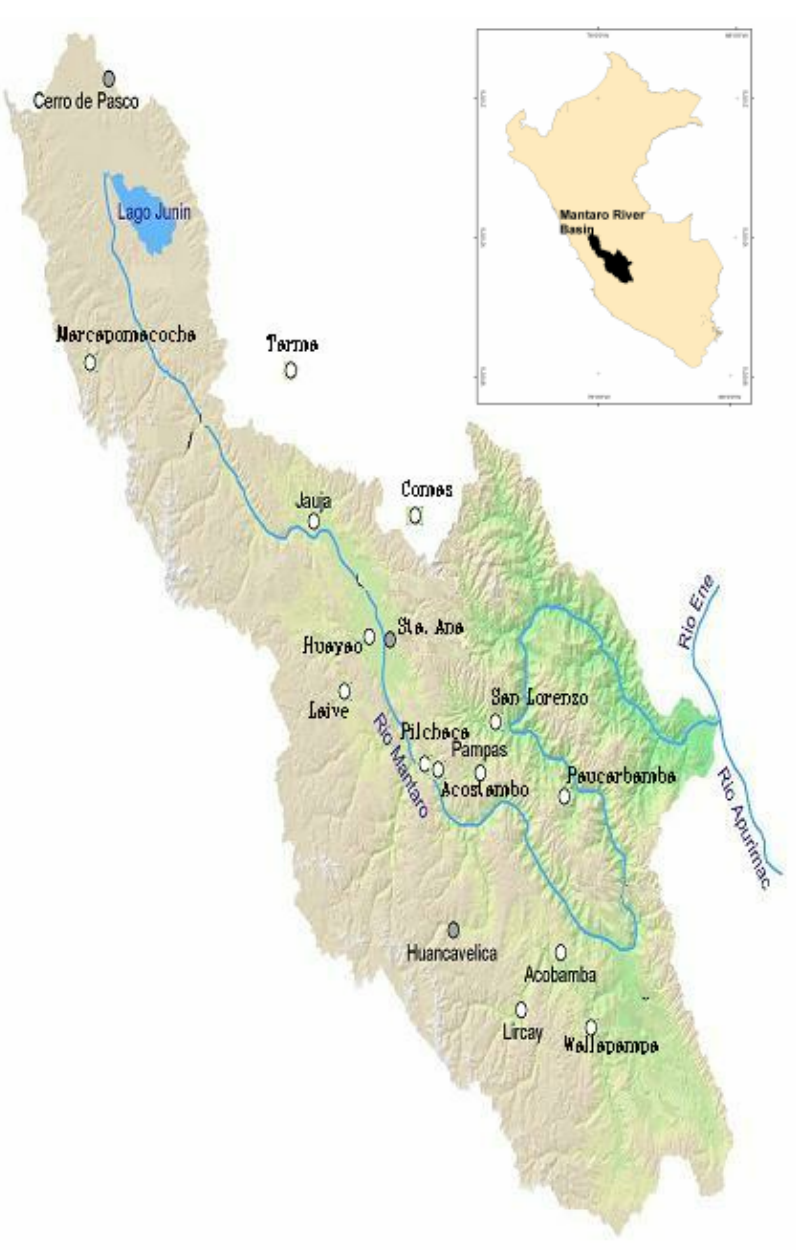

Fig. 1. The Mantaro river basin. Meteorological network used.

\section{Methodology}

First, the quality of the data was controlled, excluding all the obvious suspicious data. Other problems with the data, such as changes in instrumentation or location of the station could not be addressed with the information available. Therefore, the strength of our trend analysis lies in the robustness of the results among the different stations.

In workshops involving specialists in agriculture, "frost" was defined to occur in days in which $T_{\min }$ was lower or equal than a threshold value of $5^{\circ} \mathrm{C}$. The determination of this threshold was based on the sensitivity to temperature of the main crops (maize, potato, artichoke) in the basin, particularly in the valley, and does not necessarily imply freezing of the plants; other thresholds values $\left(-4^{\circ} \mathrm{C},-2^{\circ} \mathrm{C}, 0^{\circ} \mathrm{C}\right.$ and $2.5^{\circ} \mathrm{C}$ ) have been considered in additional analyses. Since our interest was to analyse the frost risk in the period of major agriculture activities in the region, we focused our analysis on the rainy season (from September to April). Thus, the number of frost days in the rainy season (hereafter "frost frequency") was determined for each year and the lowest value
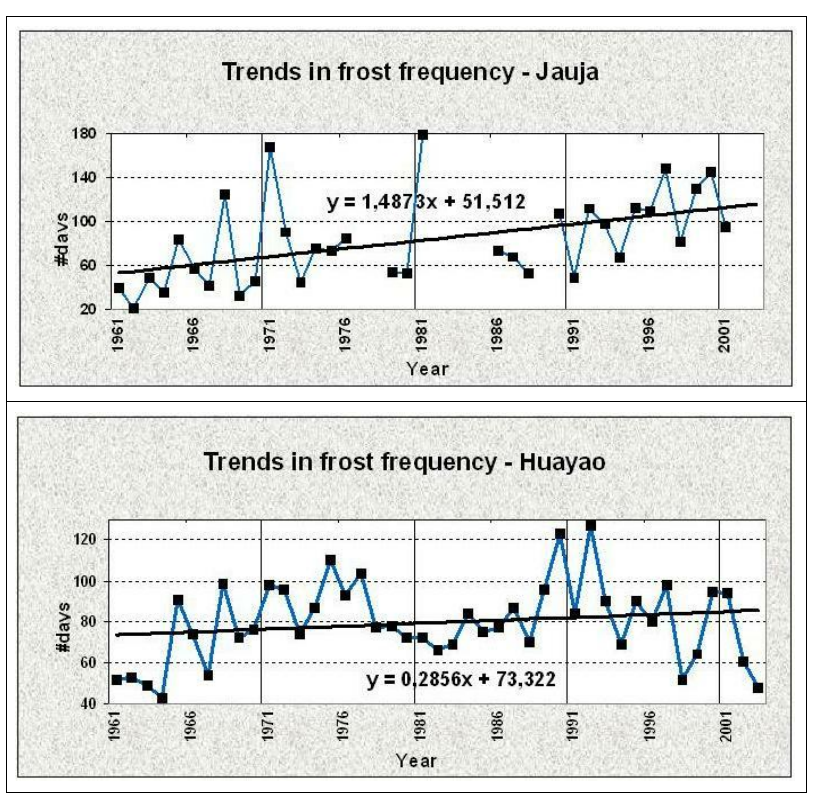

Fig. 2. Historical trends in frost frequency. Mantaro river basin.

of $T_{\min }$ for each rainy season was taken as indicator of the "frost intensity" of that year.

We determined the existence of linear trends in the annual frost frequency and intensity, using regression analysis with the least squares method. Finally, maps of empirical frost probability occurrences were produced for different thresholds $\left(5^{\circ} \mathrm{C}, 2,5^{\circ} \mathrm{C}, 0^{\circ} \mathrm{C},-2^{\circ} \mathrm{C}\right.$ and $\left.-4^{\circ} \mathrm{C}\right)$ for the entire watershed, based on a combination of linear until seventh-order polynomial curves fit versus altitude, then maps of frost risk were constructed, adding and analysing layers of slope, soil types, land-use distribution, morphology, vegetation and life zones in the form of model coefficients using a GIS platform (ArcView, Spatial Analysis and Model Builder extentions).

\section{Spatial-temporal variability of frosts in the Mantaro river basin}

A strong seasonal variability exists in $T_{\min }$ in the Mantaro River Basin, with a permanent presence of frost during austral winter, approximately between the 30th pentad (early June) and the 45th pentad (middle August). A high dependence between altitude and $T_{\min }$ for the September to April period were found (IGP, 2005b), with high non-linear correlation coefficients (between 0.91 and 0.94 ). At altitudes near or higher than $4000 \mathrm{~m}$ a.s.l. (e.g. Cerro de Pasco, Marcapomacocha, Laive), frosts were found 365 days/year; in the valley (e.g. Jauja, Huayao, Santa Ana), where altitudes are ranging from 3100 to $3300 \mathrm{~m}$ a.s.l., frosts appear between middle to late April and middle September, with extreme (coldest) values in July. In lower zones (e.g. Paucarbamba and San Lorenzo, 3000 and $2600 \mathrm{~m}$ a.s.l. respectively), the period and 

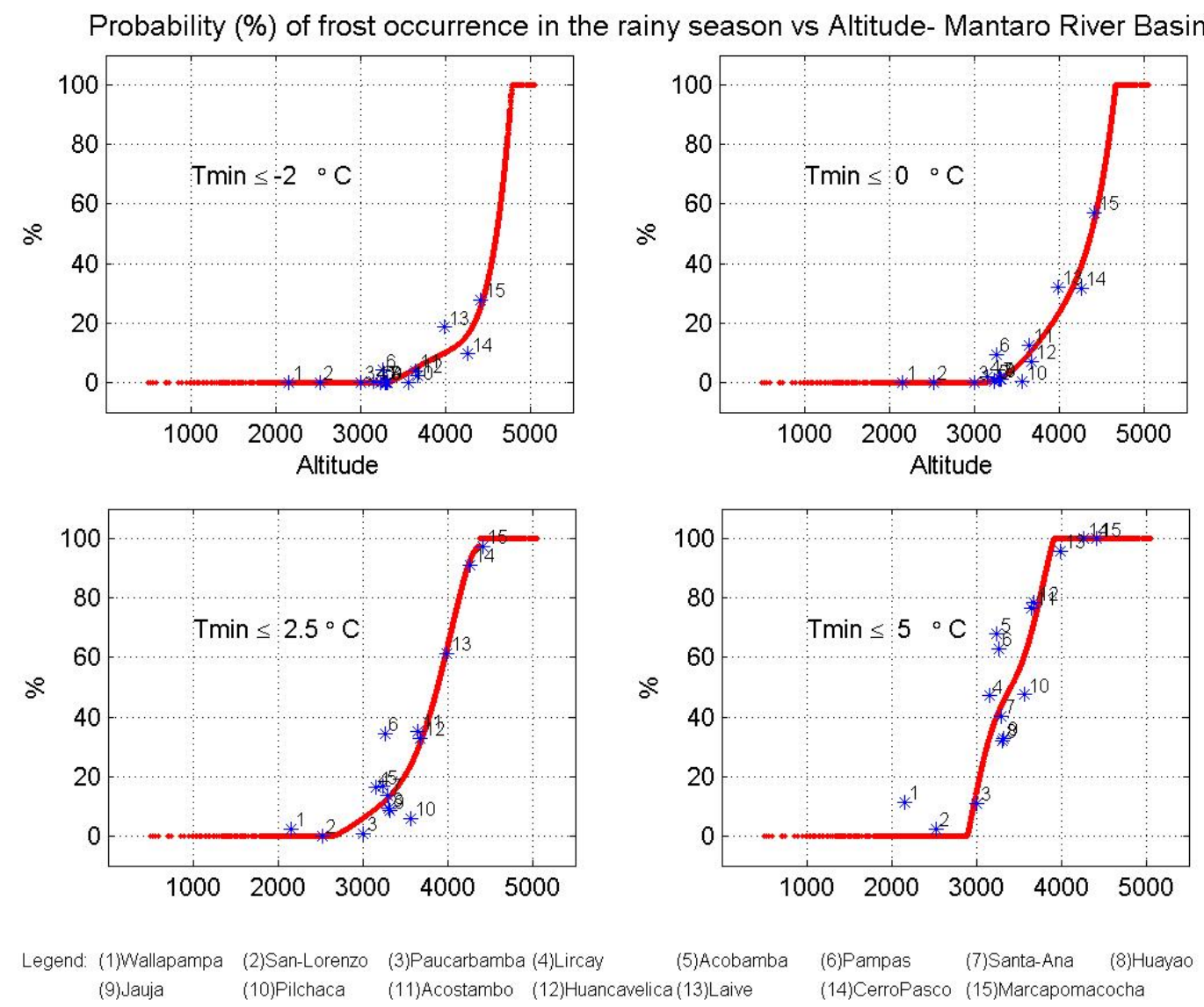

Fig. 3. Probability of frost occurrence in the rainy season (September to April) vs. altitude, threshold values of: $-2.0^{\circ} \mathrm{C}$ (upper left), $0^{\circ} \mathrm{C}$ (upper right), $2.5^{\circ} \mathrm{C}$ (down left) and $5.0^{\circ} \mathrm{C}$ (down right). Mantaro river basin.

number of days with frost is reduced to the coldest months of the year (June to August) with frost-free periods of 300 to 360 days/year.

There is a large inter annual variability in $T_{\min }$, with periods of low $T_{\min }$ (less than normal) in the middle eighties and early nineties. On the other hand, during the strong El Niño event 1997-1998, conditions were far warmer than normal registered in almost all the basin, especially between December 1997 and April 1998, with an extreme anomaly of $+4.7^{\circ} \mathrm{C}$ registered in the valley (Huayao) on February 1998, in general, the period and frequency of frosts by year was reduced considerably.

\section{Mean and trends in frequency and intensity of frosts}

The highest frequency of frosts occurs between June and August during the dry season of the region, maximizing in June or July; they are mainly associated with radiative cooling at night or dawn hours, originated by cloudless, very dry, cold and highly stable atmosphere (Villegas, 1991; IGP, 2005a). Conversely, the lowest frequency of frosts occurs between
January and March (the peak of the rainy season), and it is associated with moist and cloudy skies; in these cases frosts are normally originated by the anomalous intrusion of cold and dry air masses advected from the southern part of the continent (Garreaud and Wallace, 1998). Frosts that cause the largest impact on agriculture in the region are those that happen between the sowing and harvesting time, occurring from September to April.

At higher elevations (Marcapomacocha and Cerro de Pasco), we found a positive tendency (+3 and +6 days/decade) in the frost frequency for the rainy period. In the locality of Jauja (north of the Mantaro Valley), it was evidenced as a trend towards a high increase of the number of frost days to the same period (Fig. 2, upper side), with a rate of $+14,8$ days/decade, the highest value found in the basin. Huayao, south of the valley, displayed a tendency of increase of $+2,8$ days per decade (Fig. 2 , down side). From all the data analyzed, Pilchaca exhibited a clear opposite tendency with a rate of $-12,7$ days/decade. To the south, Lircay had a high variability in the number of frost days between September to April, with an average trend of $+12,4$ days/decade. Statistical analysis shown that trends were significant at Huayao 

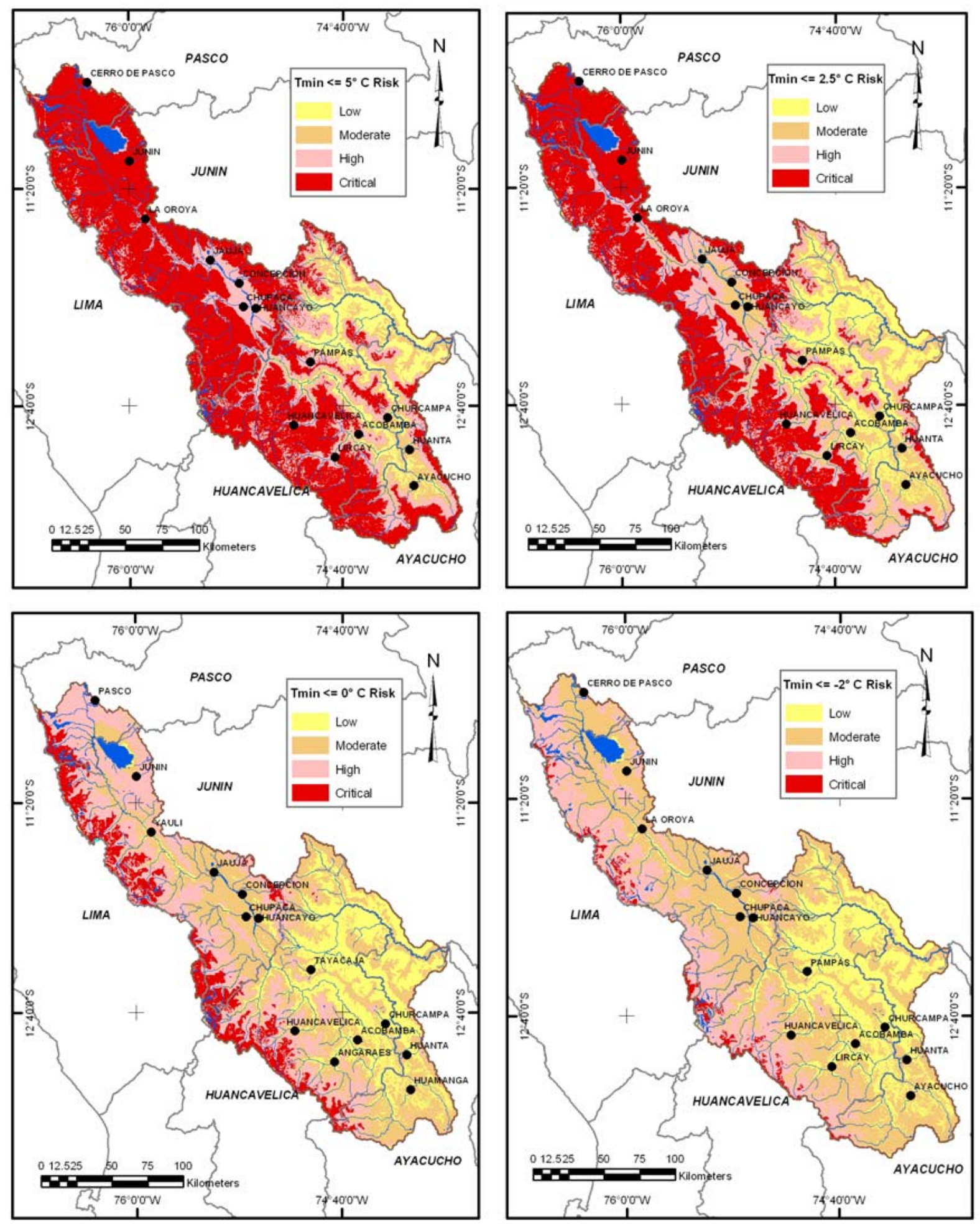

Fig. 4. Frost risk maps for the Mantaro river basin in the rainy season (September to April), threshold values of: $5^{\circ} \mathrm{C}$ (upper left, $4 \mathrm{a}$ ), $2.5^{\circ} \mathrm{C}$ (upper right, $4 \mathrm{~b}$ ), $0^{\circ} \mathrm{C}$ (down left, $4 \mathrm{c}$ ) and $-2.0^{\circ} \mathrm{C}$ (down right, $4 \mathrm{~d}$ ). Red indicates critical risk areas, pink indicates high risk areas, orange shows moderate risk areas and yellow indicates low to null risk areas. 
and Jauja with a $95 \%$ of confidence. Summarizing, a general positive historical linear trend was found in the number of days with frosts in the rainy season, with an average rate of 8 days/decade.

Frost intensity is also variable according to altitude. During September to April, $T_{\min }$ has dropped to $-9.8^{\circ} \mathrm{C}$ in highest zones like Marcapomacocha (4413 ma.s.1.); in the Mantaro Valley (Jauja, Huayao, Santa Ana), extreme frosts could reach until $-3.8^{\circ} \mathrm{C}$; in altitudes near $3000 \mathrm{~m}$ a.s.1. (Paucarbamba) frosts have not been less than $0.1^{\circ} \mathrm{C}$; and in lower zones (e.g. San Lorenzo), $T_{\min }$ were not less than $6^{\circ} \mathrm{C}$.

Changes in frost intensities in the September-April period are not robust in the Mantaro river basin. For Marcapomacocha and Cerro de Pasco, they have been less intense with time, with a rate of $0.3^{\circ} \mathrm{C}$ to $0.5^{\circ} \mathrm{C}$ per decade. On the other hand, frosts appear to be intensifying in Jauja and Lircay at a rate of -1.0 and $-0.4^{\circ} \mathrm{C} /$ decade, respectively. Huayao and Pilchaca exhibit a weak or almost null trend $\left(+0.05^{\circ} \mathrm{C} /\right.$ decade and $+0.08^{\circ} \mathrm{C} /$ decade respectively).

\section{Probability of frost occurrences and frost risks}

The relationship between probability of frost occurrences (defined as frost frequency divided by the total number of days) and altitude was empirically obtained by fitting each of the various threshold temperatures for frost conditions $\left(5^{\circ} \mathrm{C}\right.$, $2.5^{\circ} \mathrm{C}, 0^{\circ} \mathrm{C},-2^{\circ} \mathrm{C}$ and $-4^{\circ} \mathrm{C}$ ) to polynomial functions that varied between fifth and seventh order. See Fig. 3.

With these functions, we were able to produce maps of the probability of frost occurrences for the entire basin for each threshold temperature (not shown). Five categories were defined: very low probability ( $0 \%$ to $20 \%)$, low probability ( $20 \%$ to $40 \%$ ), moderate probability ( $40 \%$ to $60 \%$ ), high probability (60\% to $80 \%)$ and very high probability (80\% to $100 \%)$. For the rainy season, the probability of frost occurrences $\left(T_{\min } \leq 5^{\circ} \mathrm{C}\right)$ was very high for altitudes higher than 3800 masl $\left(4500 \mathrm{~m}\right.$ a.s.l. in case of $\left.T_{\min } \leq 0^{\circ} \mathrm{C}\right)$, which are typically found in the northern and western side of the basin; for the Mantaro valley the probability was between low and moderate (20\%-60\%); and in the lower zones (less than $2500 \mathrm{~m}$ a.s.1.) located in the central-eastern and south-eastern area, an interval of $0 \%$ to $20 \%$ is expected. In general, as the threshold temperature is decreased, the probability of occurrence of frosts decreases and is restricted to higher zones of the river basin in such a way that severe frosts $\left(T_{\min } \leq-2^{\circ} \mathrm{C}\right)$ were limited to altitudes higher than $4500 \mathrm{~m}$ a.s.1., while the threshold of $-4{ }^{\circ} \mathrm{C}$ yielded a practically null probability of occurrence throughout the river basin.

Lastly, four types of frost risks (low, moderate, high and critical) were recognized. For the $5^{\circ} \mathrm{C}$ threshold (Fig. 4a), critical risks are related to high altitudes on the basin (4000 m a.s.1.), while low (or null) frost risks are in lower zones (less than $2500 \mathrm{~m}$ a.s.l.). In the Mantaro valley, moderate to high frost risks are expected, considering the large agri- cultural activity in the region and the high sensitivity of the crops to frosts. For the threshold of $2.5^{\circ} \mathrm{C}$ (Fig. $4 \mathrm{~b}$ ), a moderate risk would prevail in the valley and between high and critical risk in altitudes greater than $3500 \mathrm{~m}$ a.s.l.; in cases of $0^{\circ}$ and $-2^{\circ} \mathrm{C}$ threshold values (Figs. $4 \mathrm{c}$ and $\mathrm{d}$ ), there will be low (or null) risk in altitudes lower than $3000 \mathrm{~m}$ a.s.l., and will decrease frost risk in the Mantaro valley between low and moderate condition.

\section{Conclusions}

There is a high relationship between frost characteristics and altitude in the Mantaro river basin. This allowed us to map some of these characteristics all over the basin based on orographic data.

Trend analysis shows that the frequency of frost days (with $T_{\min } \leq 5^{\circ} \mathrm{C}$ ) has been increasing in the rainy season (September to April), with an average rate of 8 days/decade. However, there is no a clear regional tendency in frost intensities for the same period.

Four types of frost risks were recognized in the Mantaro river basin: low, moderate, high and critical. The critical risks (and very high probability of occurrence) are related to high altitudes on the basin (altitudes higher than $3800 \mathrm{~m}$ a.s.1.), while the low (or null) frost risks are in the lower zones (less than $2500 \mathrm{~m}$ a.s.1.) with a very low probability of occurrence. The Mantaro valley (altitude between 3100 and $3300 \mathrm{~m}$ a.s.1.), can expect between moderate and high frost risks, due to the important agricultural activity and the high sensitivity of the crops to frosts (with a low to moderate probability of occurrence).

Acknowledgements. This study was made as a part of the Integrated Assessment of the Mantaro River Basin Project, developed by the Geophysical Institute of Peru, inside the PROCLIM Program and in coordination with the National Council for the Environment (CONAM) of Peru, with financial support of The Royal Netherlands Embassy. The authors also express their thanks to Dr. Ken Takahashi for his important comments and suggestions to this paper and to Eng. Ricardo Zubieta for his support in GIS post-processing.

Edited by: P. Fabian

Reviewed by: M. Zak and P. Fabian

\section{References}

Garreaud, R. D. and Wallace, J. M.: Summertime incursions of midlatitude air into subtropical and tropical South America, Mon. Wea. Rev., 126, 2713-2733, 1998.

IGP: Diagnóstico de la Cuenca del Mantaro Bajo la Visión del Cambio Climático. Fondo editorial del Concejo Nacional del Ambiente, Lima-Perú, 90 pp., 2005 a.

IGP: Atlas Climático de Precipitación y Temperatura del Aire en la Cuenca del Río Mantaro. Fondo editorial del Concejo Nacional del Ambiente, Lima-Perú, 107 pp., 2005 b. 
Villegas, E.: Zonificación del Valle del Mantaro según la Intensidad y Riesgo de Ocurrencia de Heladas Radiacionales, Tesis para optar el título de Ingeniero Meteorólogo, Universidad Nacional Agraria La Molina, 134 pp., 1991. 